Article

\title{
The influence of advertising on children's buying behaviour: A Case study in Slovakia
}

\author{
Nikoleta Hutmanová ${ }^{1}$, Zuzana Hajduová ${ }^{2, *}$, Lubor Jusko ${ }^{3}$ and Ludovít Molitoris 4 \\ ${ }^{1}$ University of Economics in Bratislava, Department of Corporate Finance, Faculty of Business Management \\ Dolnozemská cesta 1, 85235 Bratislava; nikoleta.hutmanova@euba.sk \\ ${ }^{2}$ University of Economics in Bratislava, Department of Corporate Finance, Faculty of Business Management \\ Dolnozemská cesta 1,852 35 Bratislava; zuzana.hajduova@euba.sk \\ ${ }^{3}$ University of Economics in Bratislava, Department of Corporate Finance, Faculty of Business Management \\ Dolnozemská cesta 1, 85235 Bratislava; lubor.jusko@euba.sk \\ ${ }^{4}$ University of Economics in Bratislava, Department of Corporate Finance, Faculty of Business Management \\ Dolnozemská cesta 1, 85235 Bratislava; ludovit.molitoris@euba.sk \\ * Correspondence: zuzana.hajduova@euba.sk
}

\begin{abstract}
Advertising is a very important tool in influencing the customer's buying behaviour. However, customers tend to have various levels of understanding and decoding advertising messages. Even though children do not have purchasing power themselves, they still create a key customer segment that can influence the purchase decision of the whole family. The paper focuses on how media usage by children and their attitudes towards advertisements determines their buying behavior. We analyze the development of their advertising literacy and the most important predictors of this development. The empirical study was carried out by designing a questionnaire which was filled by Slovak children between the age of 11 and 15 . We evaluated the impact of advertising and the degree of influence of the selected types of advertising media on children's consumer behavior. We also evaluated the degree of the disruptive effect of the selected types of advertising media on children and the perception of a selected medium within gender. We identified the most and the least influential type of media and we found out that there is no significant difference within gender in the case of advertising media perception by children. According to the results, we can state that children's buying behaviour is mostly influenced by advertising on social media platforms. Therefore, the study recommends for marketers also take into account children as consumers when they employ an advertising strategy on social media.
\end{abstract}

Keywords: children, advertising literacy, advertising, media, buying behaviour

\section{Introduction}

Many societal and scientific discussions about the appropriateness and fairness of advertising aimed at children have been going on for decades. One of the primary concerns in this area is that children are more sensitive to the effects of advertising than adults are because they have a low level of advertising literacy (Kunkel 2010). By advertising literacy, we mean a wide range of knowledge, attitudes, and skills needed to critically process an advertising message. It incorporates a conceptual and attitudinal dimension that gradually evolves during their lives, from simple to more sophisticated knowledge of the nature and functioning of advertising (Hudders et al. 2017). The aim of the article is, on the basis of own and previous researches, to present the way in which children interact with advertising through various advertising media. In this article, we define children as a target group with an emphasis on development of their understanding of advertising. We analyse and elaborate their development and behaviour as consumers and express the assumption of the influence of advertising media on children's consumer behaviour. Furthermore, we support our 
assumptions about the issue by a research conducted on a group of Slovak children using the online method of questionnaire data collection CAWI - computer-assisted web interviewing.

\subsection{Children and advertising}

Children are increasingly confronted with advertising on television, in radio, the press, Internet, mobile phones, and other types of media. Such ads can appear in a variety of forms, e.g. in the form of images, videos, or games promoting specific brands. However, since the widespread use of mobile phones among children and teenagers and very easily accessible Internet connection, a wider range of marketing approaches has entered the issue of advertising sharing, in which the impact on a child's behaviour has not yet been sufficiently described. Therefore, we emphasize those forms of advertising that most often reach children, and are forms of digital and sponsored content associated with the persuasive design and personalized behavioural marketing. In connection with this sponsored content, we can mention the finding, that watching online videos of vloggers on YouTube, has currently become a popular leisure activity among children (Folvord et al. 2019). A recent Ofcom study found that up to $40 \%$ of children aged 8 to 11 and $52 \%$ of children aged 12 to 15 in the UK watch some vloggers or YouTube personalities (Ofcom 2017). In addition, 49\% of 8 to 11-year-olds would rather watch content on YouTube than traditional television programs, while only $14 \%$ still prefer traditional television programmes. Vloggers with a large number of followers and a significant influence on the decision-making of their followers, also known as social media influencers, often integrate sponsored content into their vlogs in exchange for financial or non-financial reward (i.e. vlog advertising or sponsored vlogging). This integrated type of advertising therefore must be taken into account because children are considered as followers, who need to be encouraged to apply their advertising developing literacy efficiently (Ofcom 2019).

\subsection{Developing of the theory of mind}

Children start to distinguish advertising from non-commercial media content around the age of five (Livingstone, Helsper 2006), and around the age of eight, most children gain a general understanding of the advertising's selling intent and can understand the meaning of reviews. Between the age of eight and eleven, children also begin to understand the persuasive intent of advertising, which is the knowledge about that advertising is created to gain a favorable view of products. The persuasive intent itself is more difficult to understand for children than the selling intent in relation to the theory of mind, because the persuasive intent relates to changes in beliefs, while the selling intent refers to changes in behavior (Hoek et al. 2020). The cognitive perspective suggests that individual differences between children's social development can only be assessed once they have developed a so-called theory of mind. The mentioned concept of the theory of mind was first defined by the American psychologists Premack and Woodruff. According to them, it means the ability to think about the mental states of others. Thanks to this ability, individuals are further able to understand and predict the behavior of others. A good level of the development of the theory of mind allows an individual to reach for different reactions in different social situations. Terms such as "mind reading" or "mentalization" are also used in the literature to describe this term in more detail (Goldman 2012).

However, in simple terms, the theory of mind explains that children need to develop the ability to understand another person's perspective because they need a mental basis to understand that there are various other important prerequisites for understanding persuasive intents (Moses et al. 2005). In relation to theory of mind, children later develop an attitudinal advertising literacy, which consists of skepticism and disliking (Rozendaal 2016; Steffi 2020). Skepticism is a tendency not to trust advertising, while a sense of disliking is a general negative attitude towards advertising. Critical views on advertising begin to develop around the age of eight and become more negative as children move into adolescence. Typically, advertising literacy develops in parallel with their understanding of the persuasive intents of advertising. The more they are aware of the persuasive intent, the better 
they understand that advertising is sometimes biased and untrue, leading to a more negative attitude towards advertising in general (Rozendaal et al. 2016). Conceptual and attitudinal advertising literacy are dispositional, which means that even if children do not actively use them, they are still present in their mind. Dispositional advertising literacy of children is grouped in advertising schemes (Hudders et al. 2017). Schemas are in this concept mental structures that people use to understand the meaning of the world. For example, advertising schemes group all the knowledge and beliefs not only about advertising in general, but about specific advertisements too (Dahlén et al. 2007).

\subsection{Advertising techniques used in media}

Advertisers repeatedly apply a variety of marketing techniques to increase sales of their products. Therefore, it is important not only to approach the traditional marketing techniques but also the latest ones used in television and other online media.

\section{Television marketing techniques}

Repetition: The marketing technique of repetition is simply the repetition of the same advertising message, the essence of which is that the knowledge of the product increases the possibility of its purchase or use. For example, Colgate has been using such advertising frequently for a long time and has been adopted by consumers to such an extent that Colgate has replaced the word toothpaste in India (Sasank 2020).

Branded animated characters: Well-known characters are used to sell a variety of products like food, toys, clothes and many others. In order to attract children and young people to their products and services, companies often create an animated branded character to promote their product. These brand characters are specifically designed for brands by marketing companies to explain and demonstrate the products to children through advertisement(Garretson et al. 2004).

Audiovisual attention - getting elements: This marketing technique is used to attract the attention of children in particular (as they have a very short attention span) through various types of catchy sound effects, loud music and VFX (Chan Wang 2019).

Celebrity endorsement: Actors, athletes, musicians, or influencers are either displayed on the product or are depicted on how they use and approve the product. It is one of the most frequently used marketing techniques, because celebrities have a large number of fans and their display on the product creates a feeling of familiarity and trust, which leads to purchase. Studies which are based on management reveal that celebrity endorsement promotes loyalty, purchase willingness and consumption promoting effects, which are the direct influence of endorsement (Chan Wang 2019).

Premium products: Toys or products that are offered for free in addition to the purchased product are mainly used to entice children to buy them. Premium products such as toys or cards are used very often. For example, a well-known Kinder Joy adds a toy to the purchased product (Sasank 2020).

Product placement: Placing an ad on a product in such a way that the viewer cannot distinguish the content from the ad. According to the implicit-persuasion model, implicit attitudes affect children's spontaneous choice and they will more likely have future automatic reactions and choose the featured product (Brown et al. 2017).

Integrated marketing strategies: Applying an integrated marketing communication is a powerful solution which can navigate the complex communications landscape effectively. This can be achieved through a systematic process that starts with detailed research on target audiences, the right channel selections, and effective messaging. Thanks to this technique children consider products recommended by their favorite cartoon character as more attractive (Gordon, 2013).

Video - news release: Video news releases are video segments by which companies send details of their products or services to news agencies to broadcast as news programs to influence young people 
and children, because those channels have consumers' trust that they will bring appropriate news to their viewers. For example, interviews with the CEO or a senior official of a company or a documentary about how a product is made, and many other things (Sasank 2020).

\section{Literature Review}

Advergames: Research has shown that games can have a positive impact on brand awareness particularly in case of interactive in-game ads, since they can uniquely present the brand in a positive and prominent manner that best reflects the brand's position. Moreover, advergames have also shown to positively affect brand attitudes and purchase intentions. A successful video game in this context with this kind of message therefore means a successful marketing campaign for advertisers (Cicchirillo 2019).

Viral marketing: Viral advertising represents a so-called "peer-to-peer communication" strategy that depends on distribution of content viral advertisements and can provide such increased value to audiences that they transform audiences from passive content receivers to active social distributors who play a key role in advertisement distribution. Viral marketing therefore has been particularly effective for teenagers because they are mostly active on social media platforms and can be easily manipulated with big discounts, free offers and attractive products (Hemsley 2016).

Tracking software and spyware: Spyware or tracking software is used by corporations to predict consumer shopping behavior. Marketers pay money to tracking software that uses cookies to analyze a person's shopping behavior so they can improve the exposure of the ad to the customer. Moreover, these online trackers can be used to gather clickstream data of an individual's web-browsing behavior. On the other hand, offline trackers can serve as devices that can measure the movement and location of individuals through their mobile devices ( Weber 2015).

Interactive online agents: An online interactive agent is a form of hidden advertising. Advertisers program bots or robots for users who initiate a conversation or have doubts about the service. Such robots are programmed to converse in a one-to-one relationship, which builds brand loyalty (Sasank 2020). Moreover, visual attention refers to applying cognitive resources to relevant information in a visual environment and is required to deal with the information. According to this, more attention paid to stimuli indicates greater relevance to the consumer's needs and can lead to a higher chance of purchase (Wedel, Pieters 2012).

Free webinars: Companies organize webinars to introduce new services and provide bonuses. During the webinars, the features and benefits of the services are described by company representatives and attendees are also provided with freebies (Sasank 2020).

Cross-promotion: When customers of one product or service focus on promoting a related product, it is a form of marketing promotion. For example, firms promote each other services and offers freebies to their customers if they buy their counterpart service (Sasank 2020).

Referral marketing: We distinguish two types of referral programs. One in which existing customers are paid an incentive, and another in which current customers work without pay. The second program benefits the referrer by increasing visibility, heightening his or her recognition as a specialist, or can receive as a reward a special treatment from a firm (Lee 2012).

SEM - Search Engine Marketing: A search engine is complex software which can be defined as a mechanism which allows the searcher to get most appropriate results of his online search. It helps marketers by displaying their respective ads to the right people in the right place and right time and can also build a better website ranking, driving more traffic movement to the site. Therefore, it is an essential mean to expand a webpage's visibility and increase the visibility so that consumers see their product more often than a competing product, thereby increasing their chances of buying (Zhang, Cabage 2016).

Content Marketing: Content marketing uses blogs, tutorial videos, influencer videos, and more. Marketers hire bloggers, influencers and content creators to promote their product by various means 
so that they can easily target the younger generation, such as a creative content YouTube channel can promote a product without its viewers knowing, and therefore subconsciously increase product exposure. It is an easily accessible platform for children and has low barriers for participation with a simple and intuitive interface design. Its multimodal features like audio, text, special effects, animated characters can easily gain children's attention (Neumann et al. 2020).

\subsection{How children process advertising message}

For a marketing campaign to be successful, advertisers need to persuade children to notice the message, crave a specific product (or service), recognize and remember the product, and buy it. Commercial success depends on children's knowledge of advertising, which is simply created, processed and manifested in the child's mind on the basis of the following scheme (Fig.1):

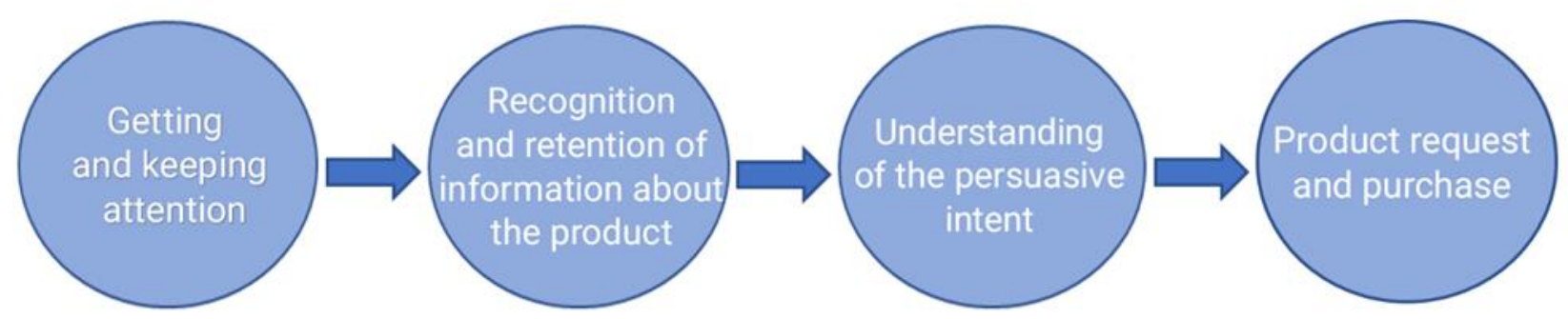

Figure 1. Advertising message processing scheme

Source: Own processing according to Sasank, 2020.

Attention: Children have a tendency to believe without a doubt the messages in the advertisement. Children's attention level on viewing television advertisement can therefore lead to children's product request, and children force parents to purchase unneeded items after seeing advertisements. (Bamfo et al.2019). Sound elements are important in attracting children's attention. According to previous studies, children aged between three and eight pay more attention to advertisements with loud sound and complex visuals. Audio elements have more recruiting power than visual elements because they can gain the viewer's attention even when they are not watching television. On the contrary, awareness of the content and less attention paid to the sound effect in older children suggests that younger children are more prone to manipulation of advertisements than older children, which supports Piaget's theory ( Sasank 2020).

Recognition and Retention: Advertising uses audiovisual and repetitive means to enhance the memory traces of the particular product. The study showed that young children remembered more about the product if they were shown an audiovisual or visual element, and not just a simple audio. Children between the age of 3 to 4 react to the change between the program and the advertisement, because of the different audiovisual elements of these two contents rather than the understanding of the difference between them (Livingstone et al. 2004). Moreover, according to further researchers, children's liking for TV advertisements results into strong recall and high levels of recognition for adult targeted advertisements. Children's liking or dislike also depends upon the nature of the product being advertised (Chan 2003).

Comprehension of commercial intent: Children under the age of eight do not understand that advertisers intend to convince them of the advantage of their product over the competition, but they simply perceive advertising as a source of information about the attractive products they can buy (Sasank 2020). In a study on development in middle childhood, Thomas Robertson and John Rossiter 
asked first-, third- and fifth-year students about their understanding of advertising, with only $50 \%$ of first-year students able to identify the advertiser's persuasive intent, while $87 \%$ of third-year students and $99 \%$ of fifth-year students were able to identify a persuasive intent (Robertson, Rossiter 1976).

Requests for products and purchases: Repetition drastically increases the demand for a product (drinks, telephone, toys, etc.) compared to other means. To support this finding, a study was performed in two groups (children aged three to eleven). One group was repeatedly shown a specific ad and the other was a control group. Both groups were sent with their mothers to a fictitious grocery store. Children from the control group had very low product requirements compared to the other group. Consequently, we can mention that children's role in the family buying decision-making process varies. From marketers' point of view in case of consumers, families receive the biggest attention as a primary and powerful decision-making unit. Children's influence on what the family buys can therefore affect everything from the less expensive to the most expensive product (Ahamad, Sekhar 2014).

\section{Materials and Methods}

The aim of this research is to evaluate the impact of advertising on children's consumer behavior through the analysis and interpretation of the results of a questionnaire survey.

The following partial goals were set:

- Evaluate the dependence between the type of advertising medium and the degree of influence on children's purchasing decisions.

- Evaluation the dependence between the type of advertising medium and the degree of disruptive effect on the child.

To evaluate the dependencies between advertising and children, we set the following hypotheses:

- We assume that there is a relationship between the type of advertising medium and the degree of influence on children's purchasing decisions.

- We assume that there is a relationship between the type of advertising medium and the degree of disruption to the child.

The study was conducted on children between age of 10 and 15. Due to the peculiarities of their development, these children develop their first consumer habits and are already fully aware of their role as consumers, and are prone to the influence of advertising on various products.

As a survey method, we used an online method of questionnaire data collection CAWI computer assisted web interviewing. The aim of the questionnaire was to find out whether advertising has an impact on children's consumer behavior and to analyze their relations to advertising media depending on the gender. In the questionnaire, we used closed, semi-closed questions and questions with interval scales examining the respondent's level of experience. An electronic questionnaire was sent to 135 secondary school students. The sample of respondents included $55 \%$ of boys and $45 \%$ of girls. The share of respondents in absolute terms is 61 girls and 74 boys between the age of 11 and 15 . The average age of the respondents was 13 years.

In addition to the four basic demographic questions of the questionnaire, the questionnaire survey consisted of eleven questions. Their number has been adjusted to the fact that children at this age have a problem maintaining attention in activities that are less interesting to them. The included questions were focused on finding out the impact of advertising on children, on finding out their experience with shopping and general attitude towards individual advertising media which, according to their own evaluation, influence them the most or, on the contrary, disturb them. The freely available Google Forms application for the distribution and processing of questionnaire answers was used for the analysis of the results, the computer program Excel was used to create graphic presentations and the SAS software was used to verify the established hypotheses. 


\section{Results}

Based on the correlation (Tab.1), according to the Pearson's correlation coefficient we found out that children who are disturbed by Internet advertising are also disturbed by television advertising and advertising on social media platforms. At the same time, those who are influenced by TV advertising are also influenced by Internet advertising.

Table 1. The relationship between the influence and the degree of disruptive effect of the advertising media on children.

\begin{tabular}{|c|c|c|c|c|c|c|c|c|c|c|}
\hline & Age & $\begin{array}{c}\text { Did youl } \\
\text { persuade } \\
\text { your } \\
\text { parents? }\end{array}$ & $\begin{array}{c}T V \text { influe } \\
\text { nce }\end{array}$ & $\begin{array}{c}\text { Billboard } \\
\text { s_influen } \\
c e\end{array}$ & $\begin{array}{c}\text { Soclal } \\
\text { networks } \\
\text { influenc } \\
e\end{array}$ & $\begin{array}{c}\text { Internet } \\
\text { ads_influ } \\
\text { ence }\end{array}$ & TV_bothe & $\begin{array}{l}\text { Billboard } \\
\text { s_bother }\end{array}$ & $\begin{array}{c}\text { Social } \\
\text { networks } \\
\text { bother }\end{array}$ & $\begin{array}{c}\text { Internet } \\
\text { ads_both } \\
\text { er }\end{array}$ \\
\hline $\begin{array}{l}\text { Age } \\
\text { Did you persuade }\end{array}$ & 1.00 & & & & & & & & & \\
\hline your parents? & -0.14 & 1.00 & & & & & & & & \\
\hline TV influence & -0.10 & 0.18 & 1.00 & & & & & & & \\
\hline $\begin{array}{l}\text { Billboards_influence } \\
\text { Social }\end{array}$ & 0.09 & -0.10 & 0.28 & 1.00 & & & & & & \\
\hline networks_influence & -0.07 & 0.21 & 0.26 & 0.12 & 1.00 & & & & & \\
\hline Internet ads_influence & 0.04 & 0.12 & 0.36 & 0.24 & 0.47 & 1.00 & & & & \\
\hline TV_bother ${ }^{-}$ & 0.11 & -0.07 & -0.03 & -0.06 & -0.07 & 0.02 & 1.00 & & & \\
\hline $\begin{array}{l}\text { Billboards bother } \\
\text { Social }\end{array}$ & 0.01 & -0.08 & -0.15 & -0.07 & 0.10 & -0.13 & 0.42 & 1.00 & & \\
\hline networks bother & 0.16 & -0.09 & 0.01 & -0.01 & -0.10 & 0.01 & 0.24 & 0.06 & 1.00 & \\
\hline Internet ads_bother & 0.16 & -0.11 & 0.03 & 0.02 & -0.11 & -0.02 & 0.56 & 0.25 & 0.49 & 1.00 \\
\hline
\end{tabular}

Based on these findings, we also looked in more detail at the degree of impact of advertising within individual media. We asked the children to what extent the given advertising medium influences them the most in their purchasing decisions (Fig.2) or, on the contrary, which advertising medium disturbs them the less (Fig.3).

Figure 2. The influence of specific advertising media on children's purchase decisions.

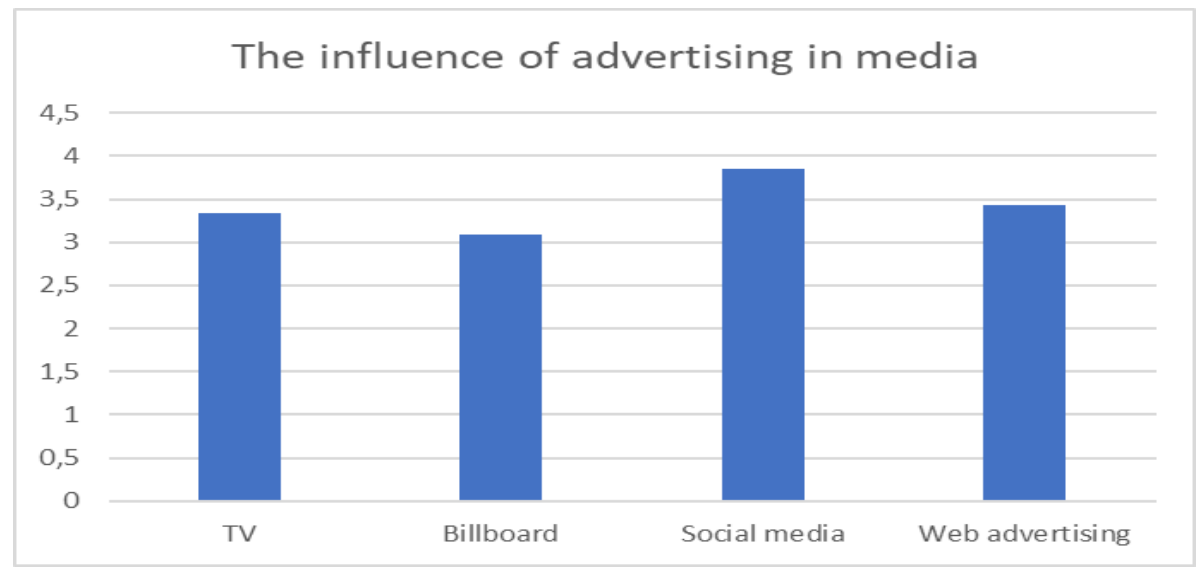

Figure 2. The influence of specific advertising media on children's purchase decisions.

Source: Own processing

Children identified as the most influential medium social media platforms, followed by advertising on the web and television. The smallest impact was identified in billboard advertising. On the other hand, web advertising and television advertising have been identified as the most 
disruptive advertising media. Social media platforms have a less disruptive effect and billboards are considered the least disruptive.

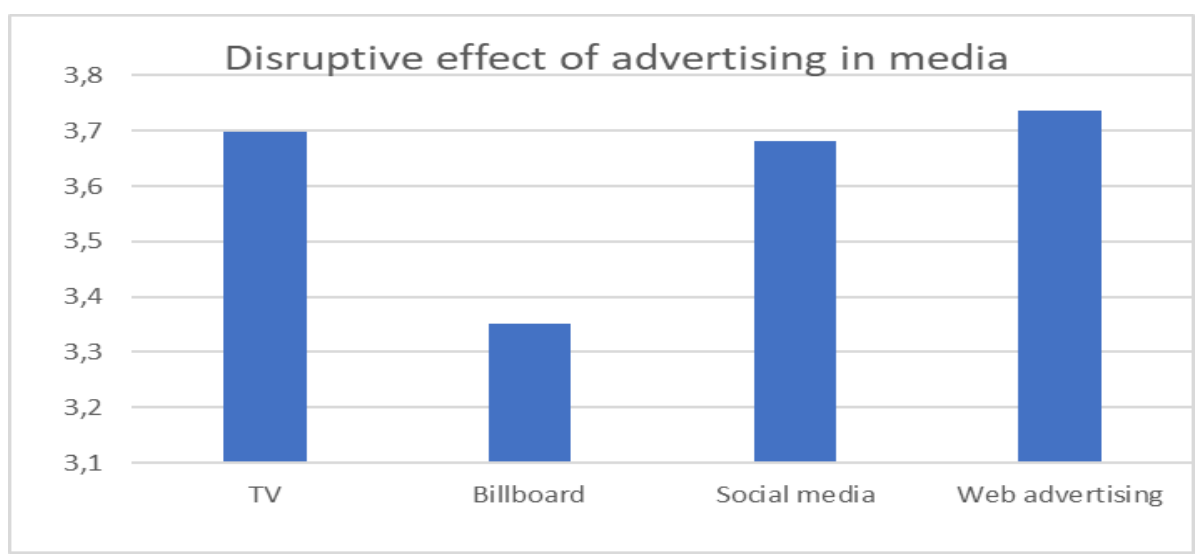

Figure 3. Disruptive effect of advertising in specific advertising media.

Source: Own processing

We have tested several hypotheses, from which we select some, such as the impact of a billboard advertising. We hypothesized the existence of a difference in the perception of billboard advertising within gender.

$H_{0}$ : The perception of billboard advertising from the perspective of boys and girls is not different.

H.: There is a difference in the perception of billboard advertising from the perspective of boys and girls.

Table 2. ANOVA

\begin{tabular}{|l|r|r|r|}
\hline Welch's & ANOVA for Billboards_bother \\
\hline Source & DF & F Value & Pr $>$ F \\
\hline Sex & 1.0000 & 7.05 & 0.0089 \\
\hline Error & 133.0 & & \\
\hline
\end{tabular}

Source: Own processing

According to these results it can be stated that there is no significant difference between the monitored groups, which are also presented by the boxplot of Figure 4 .

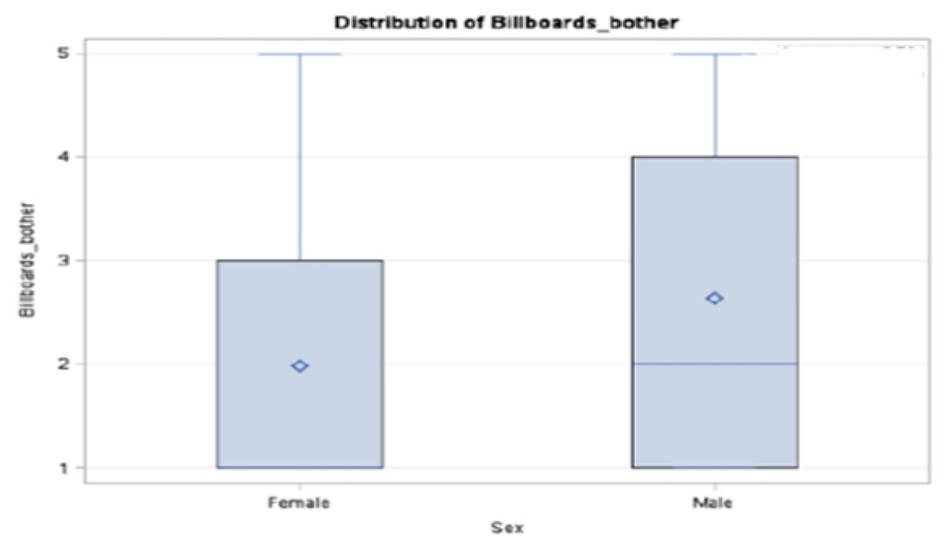

Figure 4. Boxplot 
After evaluating the influence of the type of advertising from the gender's point of view of, we can state that there is no difference between boys and girls in the degree of influence of individual types of advertising (Table 3).

Table 3. ANOVA results

\begin{tabular}{|l|r|r|r|}
\hline Welch's ANOVA for TV_infulence \\
\hline Source & DF & F Value & Pr $>$ F \\
\hline Sex & 1.0000 & 0.00 & 0.9748 \\
\hline Error & 132.9 & & \\
\hline
\end{tabular}

\begin{tabular}{|l|r|r|r|}
\hline Welch's ANOVA for Billboards_influence \\
\hline Source & DF & F Value & Pr $>$ F \\
\hline Sex & 1.0000 & 0.29 & 0.5891 \\
\hline Error & 132.9 & & \\
\hline
\end{tabular}

\begin{tabular}{|l|r|r|r|}
\hline Welch's ANOVA for Social networks_influence \\
\hline Source & DF & F Value & $\operatorname{Pr}>$ F \\
\hline Sex & 1.0000 & 1.29 & 0.2581 \\
\hline Error & 130.4 & & \\
\hline
\end{tabular}

\begin{tabular}{|l|r|r|r|}
\hline Welch's ANOVA for Internet ads_influence \\
\hline Source & DF & F Value & Pr $>$ F \\
\hline Sex & 1.0000 & 1.78 & 0.1849 \\
\hline Error & 122.4 & & \\
\hline
\end{tabular}

\section{Source: Own processing}

According to a recent research in Slovakia (Izrael et al. 2019), children are active users of social media. Previous findings state that almost $70 \%$ of children in Slovakia actively use a profile on social media platforms or on gaming platforms. Regarding to the age groups, it can be stated from the data that a third of children between age of 9 and 10, and up to 69\% of children between age of 11 and 12 use social media. Based on these facts, we decided in our research to map, specifically which social media and to what extent can influence the shopping behavior of children through placed ads (Fig.5). As many as 100 out of 135 children (74\%) stated that their buying intents are influenced by social media.

Figure 5. Degree of influence of different social media platforms

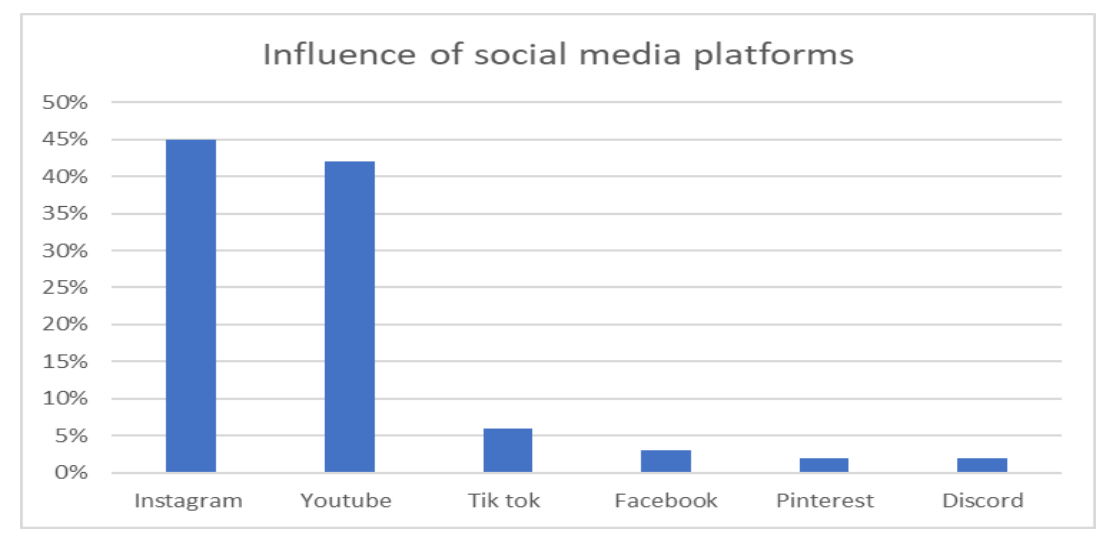

Figure 5. Degree of influence of different social media platforms 
Children's particular preferences suggest that Instagram, a social media application which focuses on visual content such as photo and video sharing, is the most influential among children in terms of the impact of ads (45\%). The second most influential platform was the video database Youtube (42\%). The TikTok mobile application and social network, designed to create and share short videos, have a much smaller influence $(6 \%)$. It is followed by a visual idea and inspiration sharing media - Pinterest (2\%). Surprisingly, only a few children stated that they are significantly affected by the well-known social media network Facebook $(3 \%)$. The least influential communication application is Discord (2\%) designed especially for gamers.

\section{Discussion and conclusion}

Based on secondary data, we found out that children in general have a low level of advertising literacy compared to adults. It gradually develops during their lives in accordance with the theory of mind and therefore can later support their understanding of advertising sharing and the persuasive intent itself. Children begin to understand the selling intent of advertising from the age of five and only later, from the age of eight, they also understand the persuasive intent of the advertising media message too. In particular, due to the massive expansion of children's use of the Internet, integrated marketing techniques are more and more frequently used to increase sales, trying to leave as much product information as possible in children's minds in order to achieve a commercial success.

We investigated the influence of advertising media on the consumer behavior of Slovak children using the online method of questionnaire data collection CAWI - computer assisted web interviewing. The sample consisted of 135 children in the age group $10-15$ years. The analysis of the results showed that within the individual advertising media, children who are disturbed by Internet advertising are also disturbed by television advertising and advertising on social media platforms. Social media platforms and advertising on the web were described as the most influential medium among children, and vice versa, advertising on the web and television were described as the most disturbing media. From the findings obtained about the use of social media platforms by children, we further investigated which social media platforms specifically have the greatest influence on children's purchasing decisions. Social media application Instagram was stated as the most influential and Youtube became the second most influential platform. Based on the results of questionnaire research and research from abroad, it can be stated that companies should also take children into account when sharing advertising content in the media, as they form an important group of potential customers. In addition, their consumer behavior can affect the whole family, and their preferences acquired in childhood can persist into adulthood.

Funding: This research was funded by Kultúrna a edukacná grantová agentúra MŠVVaŠ SR, VEGA 1/0240/20.

Conflicts of Interest: "The authors declare no conflict of interest."

\section{References}

Ahamad, S., Sekhar, N. D. C. 2014 . Family Members Rolein Purchase Decision Making. Abhinav International Monthly Refereed Journal of Research in Management \& Technology 3(8): 22-27. ISSN-2320- 0073.

Brown C.L., Matherne C.E., Bulik C.M., Howard J.B., Ravanbakht S.N., Skinner A.C., Wood C.T., Bardone-Cone A.M., Brown J.D., Perrin A.J., Levine C., Steiner M.J. \& Perrin E.M. 2017. Influence of product placement in children's movies on children's snack choices, Appetite, 3-34.

Bamfo B., Kraa, J., Asabere P.,Atarah, P.B. 2019. Effect of television adverts on children's purchase behaviour: Evidence from Ghana, Cogent Business \& Management 6:1: 1614740, DOI: 10.1080/23311975.2019.1614740.

Vincent J. Cicchirillo. 2019. Digital Game Advertising (IGA and Advergames): Not All Fun and Games, Journal of Interactive Advertising 19 : 202-203, DOI: 10.1080/15252019.2019.1697126. 
Dahlén, M., Edenius, M. 2007. When is advertising advertising? Comparing responses to non-traditional and traditional advertising media. Journal of Current Issues $\mathcal{E}$ Research in Advertising 29(1): 33-42. doi:10.1080/10641734.2007.10505206.

Folkvord, F., Bevelander, K. E., Rozendaal, E., Hermans, R. 2019. Children's bonding with popular YouTube vloggers and their attitudes toward brand and product endorsements in vlogs: An explorative study. Young Consumers20(2): 1-15, https://doi.org/10.1108/YC-12- 2018-0896.

Garretson Ja, N. R. 2004. Spokes-Character: Creating Character Trust And Positive Brand Attitudes. Journal Of Advertising 2 (33): 25-36.

Goldman, A. I. 2012. Theory of mind. Oxford Handbook of Philosophy and Cognitive Science. ISBN: 9780195309799.

Gordon, R. Unlocking the potential of upstream social marketing. European Journal of Marketing 47(9): 15251547.

Hemsley, J. Studying the viral growth of a connective action network using information event signatures. First Monday 21(8), https://firstmonday.org/ojs/index.php/ fm/article/view/6650/5598.

Hoek, R. W., Rozendaal, E., Hein. van Schie,T. and Buijzen,M. 2020. Development and testing of the advertising literacy activation task: an indirect measurement instrument for children aged 7-13 years old, Media Psychology, DOI: 10.1080/15213269.2020.1817090.

Hudders, L., De Pauw, P., Cauberghe, V., Panic, K., Zarouali, B., and Rozendaal, E. 2017. Shedding new light on how advertising literacy can affect children's processing of embedded advertising formats: A future research agenda. Journal of Advertising 46(2), 333-349. doi:10.1080/00913367.2016.1269303.

Chan W., Chen, Y., Nie and X. Wang, H.. 2019. Effects of celebrity endorsement on firms' competition: from industrial organisation perspective, Economic Research-Ekonomska Istraživanja 32:1, 3230-3252, DOI: 10.1080/1331677X.2019.1661002.

Chan, K. 2003. Parental concern about television viewing and children's advertising in China. International Journal of Public Opinion Research 15(2): 151-166. doi:10.1093/ijpor/15.2.151.

Izrael, P., Holdoš J., Hasák, M.2019. Sociálne siete a excesívne používanie internetu a sociálnych - EU Kids Online IV na Slovensku). Ružomberok: Katolícka univerzita v Ružomberku.

Kunkel, D. 2010. Mismeasurement of children's understanding of the persuasive intent of advertising. Journal of Children and Media 4(1): 109-117. doi:10.1080/17482790903407358.

Lee, B.(2012) The hidden wealth of customers Boston: Harvard Business Review Press, pp 12-13.

Livingstone, S.; Helsper, E. J. 2006 Does advertising literacy mediate the effects of advertising on children? A critical examination of two linked research literatures in relation to obesity and food choice. Journal of Communication 56(3):560-584. doi:10.1111/j.1460- 2466.2006.00301.x.

Livingstone, S. Advertising Foods to Children 2004. Understanding Promotion in the Context of Children "s Daily Lives London: LSE Research Online.

Moses, L.J. Baldwin, D.A. 2005. What can the study of cognitive development reveal about children's ability to appreciate and cope with advertising? Journal of Public Policy E Marketing 24(2): 186-201. eISSN: 15477207.

Neumann, M.; Herodotou, Ch. Young Children and YouTube. 2020.A global phenomenon, Childhood Education 96(4) :72-77, DOI: 10.1080/00094056.2020.1796459.

Ofcom. 2017. Children and Parents: Media Use and Attitudes Report. Retrieved from https://www.ofcom.org.uk/research-and-data/medialiteracy- research/childrens/children-parents-2017.

Ofcom. 2019. Children and Parents: Media Use and Attitudes Report. Retrieved from https://www.ofcom.org.uk/research-and-data/medialiteracy-research/childrens/children-and-parentsmedia-use-and-attitudesreport- 2018. 
Robertson, T., S. and Rossiter, T. 1976. Short-Run Advertising Effects on Children: A Field Study. Journal of Marketing Research $13: 68-70$.

Rozendaal, E., Lapierre, M. A., Van Reijmersdal, E. A., \& Buijzen, M. 2011. Reconsidering advertising literacy as a defense against advertising effects. Media Psychology 14(4): 333-354. doi:10.1080/15213269.2011.620540.

Rozendaal, E., Opree, S. J., and Buijzen, M. (2016). Development and validation of a survey instrument to measure children's advertising literacy. Media Psychology 19(1): 72-100. doi:10.1080/15213269.2014.88584.3.

Sasank, K., 2020. Study project report: How does Television Advertisement and Internet Advertisement affect the Children? Brila Institute of technology and science, Pilani. Available on https://www.researchgate.net/publication/344462051_How_does_Television_Advertisement_and_Interne t_Advertisement_affect_the_Children.

Steffi De Jans, Liselot Hudders 2020. Disclosure of vlog advertising targeted to children, Journal of Interactive Marketing 52: 1-19,ISSN:1520-6653.

Weber, R. H. 2015.The digital future-A challenge for privacy? Computer Law and Security Review, 31(2), 23. Wedel, M., Pieters, R. 2012. Visual Marketing: From Attention to Action. New York: Lawrence Erlbaum.

Zhang, S., Cabage, N. 2016. Search engine optimization: Comparison of link building and social sharing. Journal of Computer Information Systems, 2016, 57(2), 148-159. 